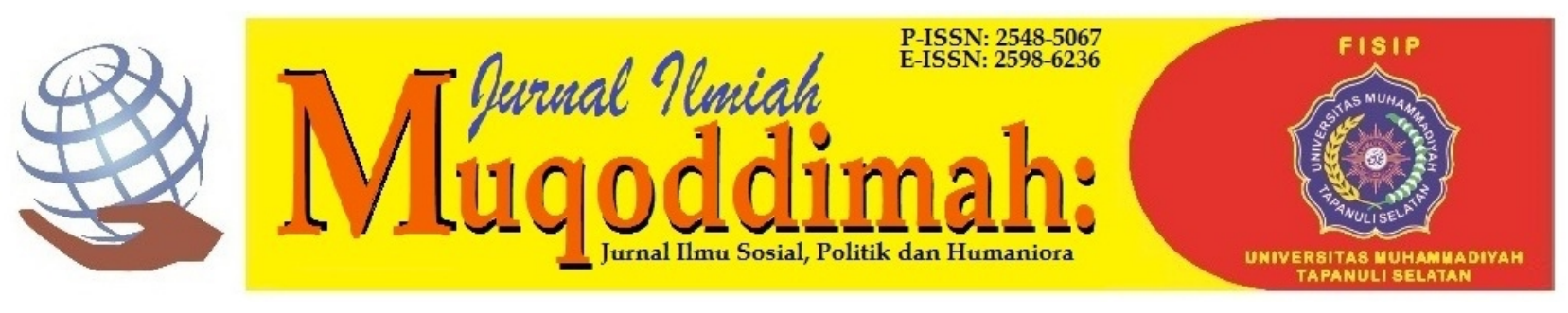

\title{
Implementasi Penerapan Sistem Manajemen Keselamatan dan Kesehatan Kerja di Dinas Lingkungan Hidup Kota Sukabumi (Studi Kasus Pada Bidang Pelayanan Kebersihan)
}

\author{
Rafly Trisesya ${ }^{1}$, Tuah Nur ${ }^{2}$, Dine Meigawati ${ }^{3}$ \\ Universitas Muhammadiyah Sukabumi \\ JI. R. Syamsudin, SH. No. 50 Kota Sukabumi, Jawa Barat, Indonesia \\ raflytrisesya22@gmail.com ${ }^{1}$ \\ tuahn309@gmail.com² \\ mrijal_amirulloh@yahoo.com ${ }^{3}$
}

\begin{abstract}
Abstrak
Sistem manajemen keselamatan dan kesehatan kerja wajib dilaksanakan oleh setiap perusahaan karena penerapan sistem manajemen keselamatan dan kesehatan kerja dilakukan berdasarkan kebijakan nasional. Tujuan dari penelitian adalah untuk mendeskripsikan dan menganalisis implementasi penerapan sistem manajemen keselamatan dan kesehatan kerja pada petugas pengangkutan sampah di Kota Sukabumi. Metode dalam penelitian ini menggunakan metode penelitian deskriptif dengan pendekatan kualitatif. Penelitian ini menggunakan lima dimensi implementasi kebijakan dari Van Meter Van Horn. Dari penelitian diperoleh kesimpulan bahwa implementasi penerapan sistem manajemen keselamatan dan kesehatan kerja pada petugas pengangkutan sampah di Kota Sukabumi sudah berjalan dengan baik jika dilihat dari sisi ukuran dan tujuan kebijakan serta karakteristik agen pelaksana. Namun dari sisi sumber daya, sikap atau kecenderungan pelaksana, komunikasi antarorganisasi dan aktivis pelaksana, dan lingkungan ekonomi sosial dan politik belum berjalan dengan baik. Hal tersebutlah yang menghambat keberhasilan dari implementasi penerapan sistem manajemen keselamatan dan kesehatan kerja.
\end{abstract}

Kata kunci: Implementasi, Kebijakan, Manajemen

\begin{abstract}
An occupational safety and health management system must be implemented by every company because the implementation of an occupational safety and health management system is carried out based on national policies. The purpose of the study was to describe and analyze the implementation of the occupational health and safety management system for waste transport officers in Sukabumi City. The method in this study uses descriptive research methods with a qualitative approach. This study uses five dimensions of policy implementation from Van Meter Van Horn. From the research, it can be concluded that the implementation of the occupational health and safety management system for waste transport officers in Sukabumi City has been going well in terms of the size and objectives of the policy and the characteristics of the implementing agency. However, in terms of resources, attitudes or tendencies of implementers, communication between organizations and implementing activists, and the economic, social and political environment have not gone well. This is what hinders the success of implementing the occupational health and safety management system.
\end{abstract}

Keywords: Implementation, Management, Policy 


\section{PENDAHULUAN}

Pada awal kehidupan manusia, sampah belum menjadi suatu masalah. Namun dengan bertambahnya jumlah penduduk dengan ruang untuk hidup tetap, maka semakin hari permasalahan sampah menjadi cukup besar. Hal ini jelas bila kita melihat modernisasi kehidupan, perkembangan teknologi sehingga meningkatkan aktifitas manusia. Sehubungan dengan kegiatan manusia, maka permasalahan sampah akan berkaitan baik dari segi sosial, ekonomi maupun budaya. Menurut data dari Dinas Lingkungan Hidup Kota Sukabumi, timbunan sampah perkapita untuk Kota Sukabumi adalah 0,51 Kg/Org/Hari. Dalam 1 hari, Kota Sukabumi memproduksi sampah sebanyak 171, 16 Ton. Dalam 1 tahun, Kota Sukabumi memproduksi sampah 62.808 Ton.

Berikut data produksi sampah pertahun (ton) di Kota Sukabumi yang diperkirakan terus meningkat dari tahun ke tahun:

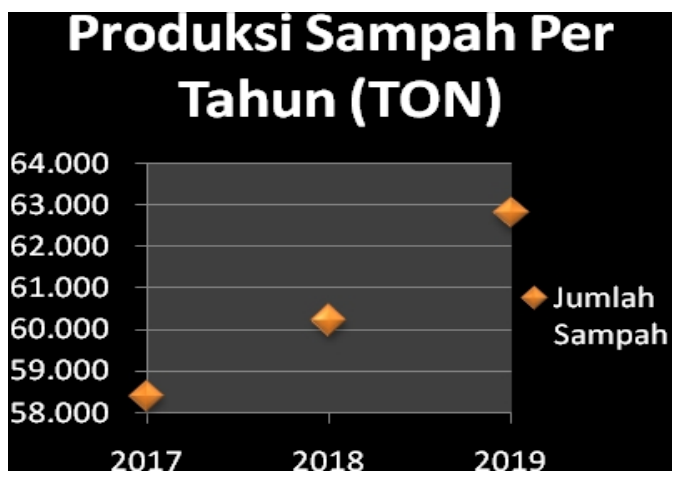

Gambar 1.1 Produksi Sampah Pertahun 2017-2019 (ton)

Dari gambar diatas dapat dilihat bahwa jumlah volume sampah mengalami peningkatan pada tahun 2019. Untuk itu, peran petugas pengangkutan sampah sangat diperlukan dalam manajemen pengelolaan sampah.

Petugas pengangkutan sampah padat dan sampah rumah tangga seringkali berkeliling antar komplek dengan truk sebagai alat penunjang kerjanya. Truk sampah adalah alat pemindahan sampah dari penghasil sampah menuju ke TPS di lingkungan pemukiman. TPS berfungsi menampung sampah dari beberapa sumber penghasil limbah dan menunggu di angkut ke TPA. Apabila sampah tidak dikelola dengan baik, maka akan memberikan pengaruh negatif yang besar terhadap kesehatan. Pengaruh negatif tersebut bisa secara langsung maupun tidak langsung. Pengaruh langsung disebabkan karena adanya kontak langsung antara manusia dengan sampah tersebut, sedangkan pengaruh tidak langsung umumnya disebabkan oleh adanya faktor yang membawa kuman penyakit yang berkembang biak di dalam sampah kepada manusia. Oleh karena itu upaya pencegahan dari kedua pengaruh negatif tersebut perlu dilakukan dengan menghindarinya atau mempergunakan Alat Pelindung Diri (APD) sebagai sistem kesehatan dan keselamatan kerja.

Kondisi manusia dikatakan tidak aman bila kesehatan dan keselamatan pekerja mulai terganggu. Dengan adanya kelelahan dan keluhan sakit pada bagian- bagian tertentu merupakan salah satu indikasi adanya gangguan kesehatan dan keselamatan pekerja. Pekerja sering mengeluh tubuh merasa nyeri atau sakit saat bekerja maupun setelah bekerja. Pekerjaan pengumpulan sampah secara manual membutuhkan kekuatan fisik yang dianggap mampu menunaikan tugas tersebut karena pekerjaan pengumpulan sampah dilakukan secara berulang seperti mengangkat sampah-sampah dari bak sampah ke truk dan mengumpulkannya ke tempat pembuangan sampah akhir. 
JURNAL ILMIAH MUQODDIMAH: Jurnal Ilmu Sosial, Politik Dan Humaniora E-ISSN : 2598-6236

http://jurnal.um-tapsel.ac.id/index.php/muqoddimah
Implementasi Penerapan Sistem Manajemen Keselamatan dan Kesehatan Kerja di Dinas Lingkungan Hidup Kota Sukabumi (Studi Kasus Pada Bidang Pelayanan Kebersihan). (Rafly Trisesya, Tuah Nur, Dine Meigawati)

Pemerintah dalam hal ini telah mengeluarkan aturan mengenai kebijakan manajemen keselamatan dan kesehatan kerja yakni Peraturan Pemerintah Republik Indonesia Nomor 50 Tahun 2012 tentang Penerapan Sistem Manajemen Keselamatan dan Kesehatan Kerja. Sumber daya manusia yang kurang mendukung, yaitu dalam pengoperasian satu unit truk sampah yakni terdiri dari empat sampai dengan lima petugas pengumpul sampah, ketika ada salah satu petugas yang tidak masuk karena izin atau sakit, maka proses pengkangkutan sampah akan terhambat akibat kurang petugas. Karena banyak sampah yang harus diangkut apabila terlambat maka jam kerja akan molor.

Belum adanya Standar Operasional Prosedur (SOP) yang mengatur penerapan sistem manajemen keselamatan dan kesehatan kerja. SOP sangat dibutuhkan untuk membantu kinerja para petugas karena setiap tindakan ada prosedurnya sehingga dapat mengurangi masalahmasalah atau kekeliruan yang bisa terjadi.

Kurangnya komunikasi mengenai kesehatan dan keselamatan kerja yang dilakukan oleh Dinas Lingkungan Hidup Kota Sukabumi, hal itu terbukti dengan tidak adanya tindakan konkrit dalam pengawasan dan pelatihan sistem manajemen keselamatan dan kesehatan kerja. Serta pada komunikasi antar organisasi dalam hal ini dengan Dinas Kesehatan Kota Sukabumi, pada saat dilaksanakan pemeriksaan infeksi dari Dinas Kesehatan, partisipasi dari petugas sampah masih kurang untuk pemeriksaan infeksi tersebut. Kesadaran dari petugas pengumpul sampah yang sering mengabaikan kesadarannya pada pelaksanaan sistem manajemen keselamatan dan kesehatan kerja di tempat kerjanya.

Dalam lingkungan ekonomi, penerapan sistem manajemen keselamatan dan kesehatan kerja belum dikatakan baik. Karena pekerjaan pengumpul sampah hanya sebatas tujuan sampah terkumpul tepat padanya waktunya dan pengumpul sampah mendapatkan upah dari hasil pekerjaannya. Upah yang diberikan hanya cukup untuk kebutuhan sehari-hari saja. Sedangkan untuk biaya kesehatan keluarganya khusunya dirinya pribadi belum ter-cover oleh gaji pengumpul sampah. Dari lingkungan sosial, banyak masyarakat yang belum menyadari cara memilah sampah, contohnya sering ditemukan barang pecah belah oleh petugas pengumpul sampah yang menyatu dengan sampah lain sehingga dapat mengakibatkan kecelakaan kerja pada petugas sampah.

Dengan mengamati gejala atau fenomena yang terjadi, menunjukan bahwa penerapan kesehatan dan keselamatan kerja pada petugas pengangkutan sampah di Kota Sukabumi harus mendapatkan perhatian dari semua pihak, khususnya untuk peneliti.

Penelitian terdahulu yang digunakan oleh peneliti sebanyak tiga penelitian guna sebagai bahan rujukan dalam penelitian agar penelitian dapat mendapatkan informasi lebih yang dapat membantu peneliti dan juga merupakan sebagai perbandingan antara peneliti sekarang dan peneliti sebelumnya. Adapun penelitian terdahulu berkaitan dengan Sistem Manajemen Keselamatan Dan Kesehatan Kerja (SMK3) yakni penelitian yang dilakukan oleh Hidayah (2017) yang berjudul "Pelaksanaan Program Kesehatan Kerja dalam Meningkatkan Produktivitas Kerja Karyawan di PT. Tirta Investama Wonosobo". Penelitian kedua dilakukan oleh Nivanda (2018) yang berjudul "Penerapan Program Kesehatan dan Keselamatan Kerja pada PT. Albisindo Timber". Selanjutnya penelitian yang dilakukan oleh Damanik (2018) yang berjudul "Pengaruh Pelaksanaan Sistem Manajemen Keselamatan dan Kesehatan Kerja Terhadap Kinerja Pegawai Pada PT. Pelabuhan Indonesia (Pelindo) I Cabang Belawan."

Yang membedakan penelitian terdahulu dengan penelitian yang peneliti lakukan sekarang adalah fokus penelitian dalam penelitian ini adalah implementasi kebijakan sistem manajemen kesehatan dan keselamatan kerja pada petugas pegumpul sampah. Dan lokus penelitiannya yaitu di Dinas Lingkungan Hidup Kota Sukabumi. Selain itu perbedaan dari penelitian terdahulu dengan penelitian sekarang yaitu pada grand theory yang digunakan, peneliti menggunakan model implementasi Van Meter Van Horn. 
JURNAL ILMIAH MUQODDIMAH: Jurnal Ilmu Sosial, Politik Dan Humaniora E-ISSN : 2598-6236

http://jurnal.um-tapsel.ac.id/index.php/muqoddimah
Implementasi Penerapan Sistem Manajemen Keselamatan dan Kesehatan Kerja di Dinas Lingkungan Hidup Kota Sukabumi (Studi Kasus Pada Bidang Pelayanan Kebersihan). (Rafly Trisesya, Tuah Nur, Dine Meigawati)

\section{METODE}

Metode penelitian yang digunakan peneliti yaitu metode penelitian deskriptif dengan pendekatan kualitatif. Teknik pengumpulan data yang digunakan adalah observasi, wawancara, dan dokumentasi perusahaan. Indikator penelitian adalah implementasi kebijakan sistem manajemen keselamatan dan kesehatan kerja pada petugas pengumpul sampah di Kota Sukabumi. Lokasi penelitian di Dinas Lingkungan Hidup Kota Sukabumi yang berada di Jl. Pemuda No.71, Citamiang, Kec. Citamiang, Kota Sukabumi, Jawa Barat.

Dalam penelitian ini, peneliti menggunakan dua teknik triangulasi untuk menguji keabsahan data dari hasil penelitian lapangan, yakni triangulasi sumber dan triangulasi teknik.

Dalam penelitian kualitatif banyak memerlukan sumber data dalam melakukan penelitian tersebut, karena itu semua dapat memberikan gambaran lebih dalam proses penelitian. Data yang diperoleh dalam penelitian kualitatif ini dapat dikumpulkan dan dikerucutkan sesuai dengan kebutuhan untuk lebih lanjut dideskripsikan dalam bentuk laporan.Menurut Miles dan Huberman dalam (Sugiyono, 2017) aktivitas dalam analisis data kualitatif dilakukan secara interaktif dan berlangsung secara terus menerus sampai tuntas, sehingga datanya sudah jenuh. Aktivitas dalam analisis data, yaitu :data reduction, data display, dan conclusion drawing/verification.

\section{HASIL DAN PEMBAHASAN}

Pada tahapan ini peneliti mendeskripsikan hasil dari wawancara yang sudah dilakukan dengan informan berdasarkan dengan model implementasi Van Meter Van Horn yang mempunyai enam dimensi yaitu Ukuran dan tujuan kebijakan, Sumber daya,Karakteristik Agen Pelaksana,Sikap / Kecenderungan para Pelaksana,Komunikasi Antarorganisasi dan aktivis pelaksana, dan Lingkungan Ekonomi, Sosial, dan Politik. Selain itu juga didukung dengan menggunakan dasar hokum Peraturan Pemerintah Republik Indonesia No 50 Tahun 2012.

Berikut ini merupakan hasil dari penjelasan mengenai pembahasan dari hasil penelitian:

1. Ukuran dan Tujuan Kebijakan

Kebijakan publik menurut Jenkins dalam Wahab (2017:15) sebagai suatu serangkaian keputusan yang saling berkaitan yang diambil oleh seorang aktor politik atau kelompok aktor, berkenaan sengan tujuan yang telah dipilih beserta cara-cara untuk mencapainya dalam suatu situasi. Keputusan- keputusan itu pada prinsipnya masih berada dalam batas-batas kewenangan kekuasaan dari para aktor tersebut.

Pada dasarnya sebuah kebijakan dirancang untuk mencapai sebuah tujuan yang telah ditentukan. Implementasi kebijakan yang berhasil bisa jadi gagal ketika para pelaksana tidak sepenuhnya menyadari terhadap standar dan tujuan kebijakan.

Ukuran dan tujuan dalam penelitian ini merupakan dimensi yang penting, karena jika implementator tidak mengetahui ukuran dan tujuan dari sebuah kebijakan yang sedang dijalankan maka pada saat menjalankan kebijakan akan menimbulkan ketidaksesuaian dan kurang optimalnya pelaksanaan kebijakan tersebut. Begitupun dengan penelitian ini pihak pelaksana yang mengimplementasikan penerapan sistem manajemen keselamatan dan kesehatan kerja pada petugas pengangkutan sampah di Kota Sukabumi harus mengetahui dan memahami apa yang menjadi ukuran dan tujuan dari kebijakan tersebut, dengan demikian dapat melaksanakannya sebaik mungkin agar tercapainya tujuan yang telah diharapkan.

Pada dimensi ini peneliti menanyakan tentang apa yang melatar belakangi penerapan sistem manajemen keselamatan dan kesehatan kerja pada petugas pengangkutan sampah di Kota Sukabumi serta tindakan apa saja yang dilakukan untuk mencapai tujuan-tujuan yang diharapkan. Pertanyaan mengenai ukuran dan tujuan langsung ditanggapi oleh informan 1 yang mengatakan:

"Perihal tentang yang menjadi latar belakang dari penerapan system manajemen keselamatan dan kesehatan kerja itu untuk menimalisir adanya hal-hal yang tidak 
JURNAL ILMIAH MUQODDIMAH: Jurnal Ilmu Sosial, Politik Dan Humaniora E-ISSN : 2598-6236

http://jurnal.um-tapsel.ac.id/index.php/muqoddimah
Implementasi Penerapan Sistem Manajemen Keselamatan dan Kesehatan Kerja di Dinas Lingkungan Hidup Kota Sukabumi (Studi Kasus Pada Bidang Pelayanan Kebersihan). (Rafly Trisesya, Tuah Nur, Dine Meigawati)

diinginkan ketika sedang bekerja, seperti misalnya kecelakaan dengan memberikan APD bagi para pekerja lapangan (petugas pengumpul sampah) khususnya".

Hal senada pun dikatakan oleh informan 2 yaitu :

"Sebenarnya untuk system K3 seperti halnya yang diterapkan di perushaan swasta masih belum diterapkan. Untuk di lapangan sendiri baru menerapkan penggunaan APD yang didasarkan pada pedoman kerja dengan memberikan masker, sarung tangan, dan sepatu boot. Selain itu juga ada tunjangan seperti BPJS Ketenagakerjaan dan santunan pekerjaan. Tetapi kenyataannya yang terjadi di lapangan meskipun sudah diberikan APD tetap saja masih sada pekerja yang tidak menggunakannya".

Dalam hal ini informan 3 juga memberikan tanggapan yang senada dengan apa yang dikatakan oleh informan 1 dan 2 bahwa "Kalau disini system keselamatan dan kesehatan kerjanya lebih ke penerapan APD bagi para pekerja lapangan (petugas pengumpul sampah) yang tugasnya angkut-angkut sampah kan dan yaa yang jadi latar belakangnya biar terjaga pada saat bertugas".

Berdasarkan uraian diatas dapat diinterpretasikan bahwa implementasi penerapan sistem manajemen keselamatan dan kesehatan kerja di Dinas Lingkungan Hidup Kota Sukabumi dengan memberikan APD untuk para pekerja lapangan (petugas pengumpul sampah) yang bertugas untuk mengangku sampah setiap harinya, meskipun penerapan system keselamatan dan kesehatan kerja ini belum sama dengan apa yang diterapkan oleh perusahaan swasta, tetapi pada dasarnya dapat memberikan perlindungan bagi para pekerja sehingga dapat menimalisir hal-hal yang mengancam keselamatan dan kesehatan kerja. Hasil wawancara tersebut sesuai dengan apa yang terjadi di lapangan dimana para pekerja lapangan diberikan perlengkapan APD untuk bertugas.

Menurut Van Meter dan Van Horn dalam buku Agustino (2013: 141) Kinerja implementasi kebijakan dapat diukur tingkatan keberhasilannya jika-dan-hanya-jika ukuran dan tujuan dari kebijakan memang realistis dengan sosio-kultur yang mengada dilevel pelaksanaan kebijakan. Ketika ukuran kebijakan atau tujuan kebijakan terlalu ideal (bahkan terlalu utopis) untuk dilaksanakan dilevel warga, maka agak sulit memeang merealisasikan kebijakan publik hingga titik yang dapat dikatakan berhasil.

Dengan adanya ukuran dan tujuan kebijakan yang jelas dan rasional, serta diketahui oleh para pelaksana yaitu agar dapat meminilisir hal-hal yang tidak diinginkan seperti adanya kecelakaan kerja sehingga penerapan system manajemen keselamatan dan kesehatan kerja dapat berjalan dengan baik, meskipun pada penerapannya hanya diberikan APD sebagai alat yang dapat dijadikan sebagai pelindung diri untuk dakam bekerja, selain itu adanya pemberian tunjangan BPJS Ketenagakerjaan juga dapat dijadikan sebagai penunjang bagi keselamatan dan kesehatan kerja yang didasarkan pada pedoman kerja sebagai acuan dan pedoman dalam bekerja.

2. Sumber Daya

Pelaksanaan sebuah kebijakan perlu adanya dukungan dari sumber daya yang memadai. Dalam pandangannya Edward III (Agustino, 2013 : 150) menjelaskan bahwasanya Sumber daya utama dalam implementasi kebijakan adalah staf. Kegagalan yang sering terjadi dalam implementasi kebijakan salah satunya disebagiankan oleh karena staf yang tidak mencukupi, memadai, ataupun tidak kompeten di dalam bidangnya.

Berdasarkan pada pengertian tersebut maka sudah jelas dalam sebuah kebijakan dibutuhkanseseorang berkompeten sehingga dapat melakukan kebijakan dengan semestinya. Begitupun dalam pelaksanaan implementasi penerapan system menajemen keselamatan dan kesehatan kerja di Dinas Lingkungan Hidup Kota Sukabumi perlu adanya 
JURNAL ILMIAH MUQODDIMAH: Jurnal IImu Sosial, Politik Dan Humaniora E-ISSN : 2598-6236

http://jurnal.um-tapsel.ac.id/index.php/muqoddimah
Implementasi Penerapan Sistem Manajemen Keselamatan dan Kesehatan Kerja di Dinas Lingkungan Hidup Kota Sukabumi (Studi Kasus Pada Bidang Pelayanan Kebersihan). (Rafly Trisesya, Tuah Nur, Dine Meigawati)

dukungan dari faktor sumber dayanya yaitu pegawai. Selain Berdasarkan uraian informan 1,2, dan 3 dalam wawancara mengenai sumber daya manusia dapat diinterpretasikan bahwa jumlah para pekerja lapangan (petugas pengumpul sampah) sudah lebih dari cukup hanya saja jumlah yang banyak tersebut tidak dapat memberikan jaminan kualitas dalam bekerja yang disebakan oleh kurang tegasnya pada saat proses rekruitmen, namun menurut informan 4, 5 dan 6 bahwa jumlah pekerja yang banyak tersebut sudah sesuai dengan tugas yang dijalankan dan dalam bekerja pun sudah sesuai dengan yang ditugaskan. Selain dari sumber daya manusia yang dapat mendukung dalam implementasi penerapan system keselamatan dan kesehatan kerja factor lain seperti sumber dana juga dapat menjadi penunjang tercapainya tujuan sebuah kebijakan, dengan adanya sumber dana dapat digunakan untuk melengkapi berbagai kebutuhan yang diperlukan, seperti pembelian APD bagi para pekerja lapangan (petugas pengumpul sampah).

3. Karakteristik Agen Pelaksana

Karakteristik agen pelaksana meliputi organisasi formal dan organisasi informal yang akan terlibat pengimplementasian kebijakan publik. Hal ini sangat pennting karena kinerja implementasi kebijakan publik akan sangat cocok dengan para agen pelaksananya. Salah satu yang dapat dijadikan tujuan dari adanya kebijakan yaitu untuk dapat memenuhi kebutuhan yang disesuaikan dengan permasalahan yang terjadi. Begitupun dengan implementasi penerapan system manajemen keselamatan dan kesehatan kerja di Dinas Lingkungan Hidup Kota Sukabumi dengan menerapkan keselamatan dna kesehatan kerja untuk dapat memenuhi kepentingan para pekerja lapangan (petugas pengumpul sampah) dalam menjalankan tugasnya.

Pada dimensi ini peneliti berfokus kepada pemenuhan kepentingan dari adanya penerapan kebijakan tentang system manajemen keselamatan dan kesehatan kerja serta mekanisme pedoman kerja dalam pelaksanaan penerapan system manajemen keselamatan dan kesehatan kerja di Dinas Lingkungan Hidup Kota Sukabumi yang meliputi juklak (petunjuk pelaksanaan) dan juknis (petunjuk teknis). Mengenai pemenuhan kebutuhan kepentingan, informan 1 memberikan tanggapan bahwa "tujuan dari adanya penerapan system keselamatan dan kesehatan kerja yaa sudah pasti untuk memberikan pemenuhan kepentingan bagi para pekerja agar terlindungi".

Berdasarkan hasil wawancara dengan seluruh informan mengenai dimensi karakteristik agen pelaksana peneliti menginterpretasikan bahwa dalam implementasi penerapan system manajemen keselamatan dan kesehatan kerja di Dinas Lingkungan Hidup Kota Sukabumi telah memenuhi kepentingan keselamatan dan kesehatan kerja di Dinas Lingkungan Hidup dengan adanya pembagian APD yang dapat digunakan pada saat bertugas, selain itu adanya mekanisme yang jelas dalam pelaksanaan penerapan system manajemen keselamatan dan kesehatan kerja di Dinas Lingkungan Hidup Kota Sukabumi bagi para petugas kebersihan memberikan kemudahan serta tugas dan cara pelaksanaannya sehingga dapat menimalisir tugas yang tumpang tindih. Dengan adanya dukungan dari karakteristik agen pelaksana akan menjadi penunjang tercapainya tujuan dari sebuah kebijakan yang diterapkan.

4. Sikap/Kecenderungan Para Pelaksana

Para pelaksana kebijakan dalam melaksanakan sebuah kebijakan harus memiliki sikap yang sesuai dengan aturan yang diberlakukan ketika melaksanakannya, hal ini agar dapat meminimalisir berbagai masalah yang kemungkinan akan menjadi penghambat dalam tercapainya tujuan dari sebuah kebijakan. Pada implementasi penerapan system manajemen keselamatan dan kesehatan kerja di Dinas Lingkungan Hidup Kota Sukabumi pun pada pelaksanaannya dapat tercapai atau tidaknya sebuah tujuan akan tergantung dari sikap para pelaksananya. 
JURNAL ILMIAH MUQODDIMAH: Jurnal Ilmu Sosial, Politik Dan Humaniora E-ISSN : 2598-6236

http://jurnal.um-tapsel.ac.id/index.php/muqoddimah
Implementasi Penerapan Sistem Manajemen Keselamatan dan Kesehatan Kerja di Dinas Lingkungan Hidup Kota Sukabumi (Studi Kasus Pada Bidang Pelayanan Kebersihan). (Rafly Trisesya, Tuah Nur, Dine Meigawati)

Berkaitan dengan sikap pelaksana dari implementasi penerapan system manajemen keselamatan dan kesehatan kerja masih terdapat ketidaksesuaian dengan penerapan system manajemen keselamatan dan kesehatan kerja seperti masih adanya para pekerja lapangan yang kurang disiplin sehingga tidak menggunakan perlengkapan APD pada saat bekerja yang kenyataannya penggunaan APD tersebut sangat berguna bagi dirinya sebagai salah satu bentuk perlindungan bagi kesehatannya.

Pada dimensi ini peneliti memberikan pertanyaan kepada informan mengenai jaminan kesehatan yang mengatur dan melindungi keberadaan Petugas Pengumpul Sampah serta bentuk tindakan partisipatif oleh Kementrian Tenaga Kerja dalam mengelola penerapan sistem manajemen keselamatan dan kesehatan kerja, yang langsung diberikan tanggapan oleh informan 1 yaitu "tentunya ada jaminan kesehatan yang diberikan kepada para pekerja lapangan salah satunya seperti bpjs ketenagakerjaan".

5. Komunikasi Antarorganisasi dan Aktivis Pelaksana

Komunikasi merupakan salah satu dimensi yang dapat menentukan keberhasilan pencapaian tujuan dari implementasi kebijakan publik. Menurut Edward III (Agustino, 2013 : 150) Implementasi yang efektif terjadi apabilai para pembuat keputusan sudah mengetahui apa yang akan mereka kerjakan. Melalui penyaluran komunikasi yang baik menghasilkan suatu implementasi yang baik pula. Seringkali yang terjadi dalam penyaluran komunikasi adalah adanya salah pengertian (miskomunikasi) yang mengakibatkan adanya hambatan dalam pelaksanaan sebuah kebijakan.

Dalam penelitian ini pelaksana dari impelementasi penerapan system manajemen keselamatan dan kerja di Dinas Lingkungan Hidup Kota Sukabumi adalah bidang pelayanan kebersihan beserta para petugas lapangan pengangkut sampah. dengan demikian antara pihak bidang pelayanan kebersihan dan petugas lapangan perlu menjalankan komunikasi agar dapat menyatukan pemikiran dan pemahaman terkait bagaimana seharusnya impelementasi penerapan system manajemen keselamatan dan kerja dilaksanakan sesuai dengan peraturan yang berlaku. Selain dari bidnag pelayanan kebersihan dan para pelekerja lapangan, ada peran lain agar penerapan system manajemen keselamatan dan kesehatan kerja dapat difahami dan diketahui oleh seluruh pihak pelaksana, yaitu peran dari kementerian ketengakerjaan dalam memberikan sosialiasi kepada instansi pemerintahan dalam impmelementasi penerapan system manajemen keselamaatan dan kesehatan kerja, namun dalam hal ini menurut informan1,2, dan 3 dengan serempak mengatakan "belum adanya peran langsung dari kementerian ketenagakerjaan dengan melakukan sosialiasi mengenai kebijakan implementasi penerapan system manajemen keselamatan dan kesehatan kerja, karena mungkin untuk hal K3 lebih berfokus kepada perusahaan swasta".

Dari hasil wawancara dengan informan, peneliti menginterpretasikan bahwa komunikasi yang dilakukan oleh pihak bidang pelayanan kebersihan dan para pekerja lapangan (petugas pengumpul sampah) sudah berjalan dengan baik, hal ini berujuan untuk memberikan pengarahan tentang implemetasi penerapan system manajemen keselamatan dan kesehatan kerja serta apabila adanya permasalahan ataupun hambatan dapat terselesaikan dengan cepat. Namun dalam pelaksanaan implementasi penerapan system manajemen keselamatan dak kesehatan kerja masih belum dilaksanakan oleh semua pekerja lapangan, masih saja ada para pekerja lapangan (petugas pengumpul sampah) yang melaksanakan.

6. Lingkungan Ekonomi, Sosial, dan Politik

Hal terakhir yang perlu juga dipertahankan guna menilai kinerja implementasi publik dalam perspektif yang ditawarkan oleh Van Metter dan Van Horn adalah sejauh mana lingkungan eksternal turut mendororng keberhasilan kebijakan publik yang telah ditetapkan. Lingkungan sosial, ekonomi, dan politik yang tidak kondusif dapat menjadi biang keladi dari kegagalan implementasi kebijakan. Karena itu upaya untuk mengimplementasikan kebijakan harus pula memperhatikan kekondusifan kondisi lingkungan eksternal. 
JURNAL ILMIAH MUQODDIMAH: Jurnal Ilmu Sosial, Politik Dan Humaniora E-ISSN : 2598-6236

http://jurnal.um-tapsel.ac.id/index.php/muqoddimah
Implementasi Penerapan Sistem Manajemen Keselamatan dan Kesehatan Kerja di Dinas Lingkungan Hidup Kota Sukabumi (Studi Kasus Pada Bidang Pelayanan Kebersihan). (Rafly Trisesya, Tuah Nur, Dine Meigawati)

Pada dimensi ini peneliti memberikan pertanyaan mengenai bagaimana lingkungan ekonomi, social, dan politik dalam implementasi penerapansystem manajemen keselamatan dan kesehatan kerja di Dinas Lingkungan Hidup Kota Sukabumi. Hal ini ditanggapi langsung oleh informan 1 yang mengatakan bahwa "pada dasarnya dalam pelaksanaan kebijakan memang dibutuhkan dukuangan dari berbagai aspek dan pihak. Dalam hal ini dari segi lingkungan ekonomi, social, dan politik mendukung seperti untuk ekonomi ada yang menjadi sumber dana yaitu ABPD, dari lingkungan social juga mendukung, politik pun dengan adanya aturan sebagai bukti dukungan".

\section{SIMPULAN DAN SARAN}

Berdasarkan hasil penelitian dapat disimpulkan bahwa ukuran dan tujuan dalam implementasi penerapan sistem keselamatan dan kesehatan kerja di Dinas Lingkungan Hidup diketahui dengan jelas oleh para pelaksana dan sasaran kebijakan, sumber daya yang kurang mendukung yang disebabkan kurang tegasnya dalam sistem rekruitmen pekerja. Sedangkan untuk karakteristik agen pelaksana sudah berjalan baik karena pemenuhan kepentingan keselamatan dan kesehatan kerja disesuaikan dengan kebijakan yang berlaku.

Sikap atau kecenderungan pelaksana dalam penerapan sistem manajemen keselamatan dan kesehatan kerja belum berjalan secara optimal karena masih adanya para pekerja yang kurang disiplin sehingga tidak menerapkan apa yang sudah dijadikan sebagai aturan.

. Kelima, komunikasi yang ada sudah dapat dikatakan baik dengan adanya koordinasi pada setiap permasalahan yang ada, sedangkan dalam lingkungan ekonomi, penerapan sistem manajemen keselamatan dan kesehatan kerja belum dikatakan baik. Upah yang diberikan hanya cukup untuk memberi makan keluarganya saja. Sedangkan untuk biaya kesehatan keluarganya khususnya dirinya pribadi belum tercukupi dari gaji pengumpul sampah. Dari lingkungan sosial, banyak masyarakat yang belum menyadari cara memilah sampah.

Adapun saran yang dapat peneliti kemukakan dari hasil penelitian yang telah dilakukan:

1) Adanya sistem manajemen yang jelas pada saat rekruitmen pekerja, agar dapat meningkatkan kualitas kerja sehingga dapat mencapi target kerja yang telah ditentukan.

2) Adanya sanksi tegas bagi para pekerja lapangan yang masih saja tidak menggunakan APD pada saat bekerja.

3) Meningkatkan komunikasi yang telah terjalin, sehingga melakukan koordinasi bukan hanya pada saat ada hambatan atau pelanggaran tetapi juga melakukannya secara rutin.

4) Sebaiknya Dinas Lingkungan Hidup Kota Sukabumi memberikan upah yang layak bagi petugas pengumpul sampah dan dari segi sosial sebaiknya Dinas Lingkungan Hidup Kota Sukabumi meningkatkan antusias masyarakat dalam pelaksanaan program kebersihan dengan cara memberikan penyuluhan tentang pentingnya menjaga kebersihan dan cara pemilahan sampah.

\section{DAFTAR PUSTAKA}

Abidin, Said, Zainal. 2004. Kebijakan Publik. YayasanPancur Siwah: Jakarta.

Afrizal, Prof. Dr., M.A. 2014. Metode Penelitian Kualitatif: Sebuah Upaya Mendukung Penggunaan Penelitian Kualitatif dalamBerbagai Disiplin IImu. Depok: PT Raja Grafindo Persada

A. G, Subarsono. 2013. Analisis Kebijakan Publik. Pustaka Pelajar: Yogyakarta.

Agus, Erwan Purwanto dan Dyah Ratih Sulistyastuti. 2015. Implementasi Kebijakan Publik. Konsep dan Aplikasinya di Indonesia. Yogyakarta : Gava Media.

Agustino, Leo. 2013. Dasar- dasar Kebijakan Publik. Alfabeta: Bandung.

Arifin Tahir, 2015, Kebijakan Publik dan Transparansi Penyelenggaraan Pemerintahan Daerah. Bandung : Alfabeta 
Budi, Winarno. 2002. Kebijakan Publik: Teori dan Proses Edisi Revisi. Yogyakarta : Media Presindo.

Bungin, Burhan.2007. Penelitian Kualitatif: Komunikasi, Ekonomi, Kebijakan Publik dan IImu Sosial lainnya. Jakarta: Putra Grafika

Islamy, Irfan. 2009. Prinsip- prinsip Perumusan Kebijaksanaan Negara. Bumi Aksara: Jakarta.

Moleong, L.J. 2011. Metodologi Penelitian Kualitatif Edisi Revisi. PT. Remaja Rosdakarya : Bandung.

Sugiyono. 2014.Metode Penelitian Kualitatif Dan R\&B. Bandung: Alfabeta.

Sugiyono. 2017.Metode Penelitian Kualitatif Dan R\&B. Bandung: Alfabeta.

Sinambela. Lijan Poltak. 2017. Manajemen Sumber Daya Manusia. Jakarta: Bumi Aksara.

Wahab, Solichin. 2017. Analisis Kebijakan Dari Formulasi Ke Penyususnan Model-model Implementasi Kebijakan Publik. Jakarta: Bumi Aksara.

Winarno, Budi. 2014.Kebijakan Publik Teori, Proses dan Studi Kasus, Cetakan Kedua. Yogyakarta : CAPS.

Adnani, Hariza. 2010. Prilaku Petugas Pengumpul Sampah untuk Melindungi Dirinya Dari Penyakit Bawaan Sampah di Wilayah Patangpuluhan Yogyakarta Tahun 2000. Yogyakarta: STIKES Surya Global Yogyakarta.

Damanik, Mitha. 2018. Pengaruh Pelaksanaan Sistem Manajemen Keselamatan dan Kesehatan Kerja Terhadap Kinerja Pegawai Pada PT. Pelabuhan Indonesia (Pelindo) I Cabang Belawan. Medan : Universitas Sumatera Utara.

Hidayah. 2017. Pelaksanaan Program Keselamatan Dan Kesehatan Kerja Dalam Meningkatkan Produktivitas Kerja Karyawan Di PT. Tirta Investama Wonosobo. Yogyakarta : Universitas Negeri Yogyakarta.

Japan International Cooperation Agency (JICA).2009. A Study of Electricity Use in Multiple Jakarta Buildings.

Karuniaastuti, Nurhenu. 2013. Bahaya Plastik Terhadap Kesehatan dan Lingkungan. Jakarta : Swara Putra

Nivanda, S. 2018. Penerapan Program Kesehatan dan Keselamatan Kerja pada PT. Albisindo Timber.

Rimantho, Dino. 2015. Identifikasi Resiko Kesehatan dan Keselamatan Kerja Pada Pekerja Pengumpul Sampah Manual di Jakarta Selatan. Jakarta : Universitas Pancasila Jakarta.

Ramdhan, Achmad. 2012. Penerapan Sistem Manajemen Keselamatan Dan Kesehatan Kerja (SMK3) (Studi Pada Proyek Pembangunan Jalan Rawa Buaya, Cengkareng). Depok : Universitas Indonesia.

Dokumen Volume Sampah 2017-2019

Peraturan Pemerintah Republik Indonesia No 50 Tahun 2012 